\title{
The Impact of Soft Skills on Organizational Innovation in Lavant Food Products Company (AIDurra)
}

Haya Ziad Awawdeh, Shaker Jaralla Alkshali

To Link this Article: http://dx.doi.org/10.6007/IJARBSS/v12-i1/11568

DOI:10.6007/IJARBSS/v12-i1/11568

Received: 16 November 2021, Revised: 20 December 2021, Accepted: 30 December 2021

Published Online: 10 January 2022

In-Text Citation: (Awawdeh \& Alkshali, 2022)

To Cite this Article: Awawdeh, H. Z., \& Alkshali, S. J. (2022). The Impact of Soft Skills on Organizational Innovation in Lavant Food Products Company (AIDurra). International Journal of Academic Research in Business and Social Sciences, 12(1), $569-584$.

\section{Copyright: (c) 2022 The Author(s)}

Published by Human Resource Management Academic Research Society (www.hrmars.com)

This article is published under the Creative Commons Attribution (CC BY 4.0) license. Anyone may reproduce, distribute, translate and create derivative works of this article (for both commercial and non0-commercial purposes), subject to full attribution to the original publication and authors. The full terms of this license may be seen at: http://creativecommons.org/licences/by/4.0/legalcode

\section{Vol. 12, No. 1, 2022, Pg. $569-584$}

Full Terms \& Conditions of access and use can be found at http://hrmars.com/index.php/pages/detail/publication-ethics 


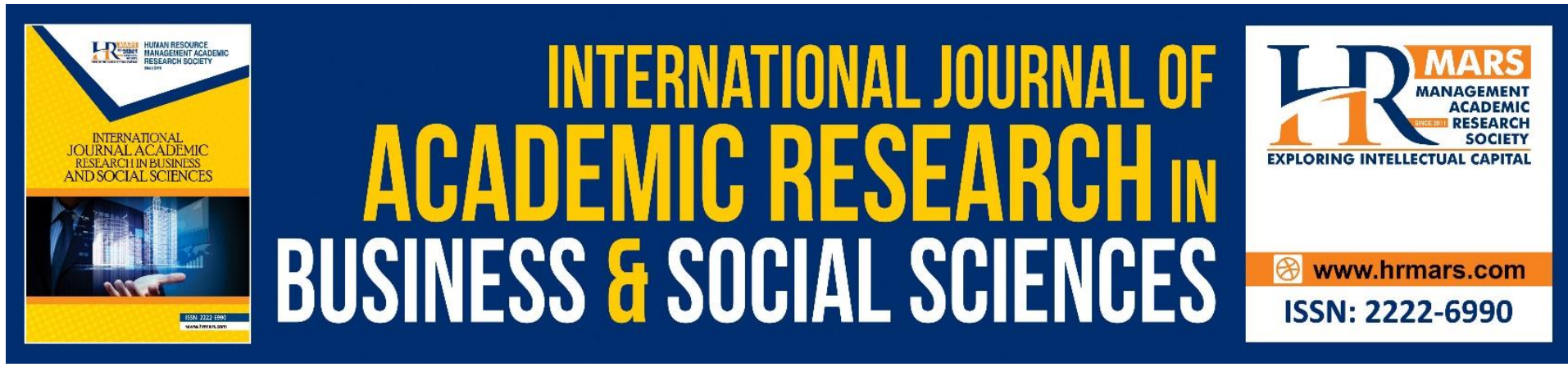

\title{
The Impact of Soft Skills on Organizational Innovation in Lavant Food Products Company (AlDurra)
}

\author{
Haya Ziad Awawdeh, Prof. Shaker Jaralla Alkshali \\ The World Islamic Sciences \& Education University, Amman, Jordan \\ Email: Hayaawawdeh3@gmail.com,drshaker55@yahoo.com
}

\begin{abstract}
The study aimed to investigate the impact of soft skills on organizational innovation in Lavant Food Products Company (AIDurra). The study was conducted on a sample of 106 employees of this company. The necessary data were collected from them through a questionnaire developed for this purpose. The study used the quantitative descriptive method. The study relied on five dimensions to measure soft skills (the independent variable), which are: communication, time management, leadership, teamwork and decision-making. With regard to organizational innovation (the dependent variable), it was measured through four dimensions: introduction new product, improve existing product, innovating new process and improve existing process. The study used a set of statistical methods, the most important of which is the multiple linear regression.

The study concluded that there are high levels of the dimensions of both variables, and that there is a significant impact of soft skills on organizational innovation, and the most influential dimensions of soft skills on organizational innovation are: leadership, decisionmaking and teamwork.
\end{abstract}

Keywords: Soft Skills, Organizational Innovation, Lavant Food Products Company (AlDurra), Jordan.

\section{Introduction}

Organizational innovation plays an important role in introducing new products or creating and developing existing products, and it may be a new organizational style or a modern organizational method in order to reach something distinct and different from the rest of the organizations, and to ensure success and continuity, continuous innovation is required to keep pace with market requirements by reducing prices, and increase the quality. Organizational innovation includes change in the organizational structure, designing business and organizational processes, excluding unimportant activities, and adopting leadership methods that increase the ability of the individual and push him to innovate.

Given the importance of the human element, which is one of the organization's basic resources, organizations pay attention to training and development to increase the experiences of their employees for their role in dealing with the changes they face. The development of soft skills that the individual possesses in terms of time management, 
teamwork, creative thinking, leadership skill, and communication with others leads to improving the productivity of workers, and increases their experience in mastering work.

Hence, the need arose for organizations with different activities and objectives to predict and anticipate the future by setting long-term goals that take into account keeping pace with modern technologies and their development within a special strategy for this organization, as this strategy is based on research and development and objectively based on appropriate scientific methods that enable the organization to prepare and face the developments, changes and circumstances that surround them, in addition to taking them into account also looking at the internal and external environments in which the organization operates. Hence, this study came to reveal the impact of strategic intelligence on organizational innovation and soft skills as an intermediary role.

The importance of this study comes due to the importance of the variables it addressed, as the concept of organizational innovation is considered one of the renewable concepts in the business world, and the concept of soft skills is one of the contemporary concepts, which the need for it has become more urgent in light of the increase in societal awareness and the need for business organizations to carry out their activities on the basis of human values for all that, the researchers seek, behind delving into these concepts, to see everything that is new and attract the attention of researchers in this field and present it within this study in order to be a tributary and a habitat for researchers and professionals, and thus fill some of the shortcomings in the Arabic library about these concepts, especially with regard to soft skills.

On the other hand, the importance of the study lies in the extent to which the departments in the Jordanian pharmaceutical factories benefit from the results they will reach, with regard to the concept of strategic intelligence, organizational innovation, and the soft skills of these companies.

The importance of the study also comes from the importance of the sector in which it will be applied, as the pharmaceutical sector is considered one of the most promising economic sectors in Jordan, in terms of its contributions to economic development. On the contrary, it was a major tributary to Jordan's economy when many other economic sectors were suffering from economic and security crises, and in terms of the dependence of many other sectors on the activity of this sector.

Globalization and the openness of global markets have led to an increase in the intensity of competition, especially in the field of industry, including the pharmaceutical industry, where competition led to the establishment of companies in this sector like companies in other sectors to search for everything that is new, whether in terms of products or in terms of operations used in the management of these companies, in addition to developing and improving the existing products and processes, all of which requires a comprehensive and integrated view of the activities of these companies, and they must have a clear vision of the future of the industry in this sector, in a way that helps them clearly define their vision, As well as their need to enter into companies with international companies that are equivalent to them and complement their activities, and the researchers believe that all of this requires these companies to possess many skills to deal with different parties, including communication skills, negotiation skills, and others. Based on the foregoing, the study problem can be formulated in the following question:

What is the impact of soft skills on organizational innovation in Lavant Food Products Company (Al-Durra)? 


\section{Study Objectives}

- Identifying the level of interest in soft skills and organizational innovation in Lavant Food Products Company (Al-Durra).

- Identifying the impact of soft skills on organizational innovation in Lavant Food Products Company (Al-Durra).

\section{Theoretical Background \\ Soft Skills}

Gregory $(1999,236)$ defined soft skills as the experience enjoyed by human resources as a result of their participation in training and development programs, and it is the second component of human capital, which plays an important role in dealing with the changes and developments that the organization faces at work. As for Al-Jaraydah and Al-Aloui (2018) they define soft skills as a set of characteristics and skills possessed by the official, such as the skill of working with a team, creative thinking, time management ability, and communication skill.

Reddy $(2013,335)$ sees that life skills and the skills necessary to get a job, are those aspects related to tact in speaking, good and distinguished appearance, and possession of the special qualities that distinguish the job seeker among his peers. While Moss and Tilly (1996) defines it as a On the other hand Gibb (2014) stated that soft skills improve the quality of human capital and thus enhance the productivity of the individual, developing the effects of soft skills facilitates performance, increases mastery experience, and engages people in work-related behaviors.

Soft skills are the personality traits, behavior and attitudes that increase professionals' interactions, career prospects and job performance. The best feature of soft skills is that the use of these skills is not limited to a specific profession. Soft skills are personal and broadly applicable (Robles, 2012).

Junrat et al. (2014) sees that soft skills are required for information professionals in their daily work, dealing with clients and colleagues effectively. Information specialists in large organizations develop these skills to some extent through practical experience. Soft skills are an individual's personal qualities, habits, attitudes, and social courtesy that enable an employee to be good and compatible with fellowship (Aldulaimi, 2018, 2). Abdullah (2013, 11) sees it as a set of personal characteristics related to the field of communication with others in a comfortable work environment in which the individual can deal with cooperation and love, and the ability to express oneself, in addition to the skills of brainstorming in smooth and attractive ways.

Soft skills are a term related to personality, positive traits and competencies that enhance a person's relationships, job performance, and give market value. Skills include one's ability to listen well, communicate effectively, have a positive approach, deal with conflict, take responsibility, and show respect. Building trust, working well with others, managing time effectively, accepting criticism, working under pressure, being kind to others and showing good character (Vijayalalshmi, 2016).

1. Communication: There is a set of skills that fall within the soft skills, such as writing skill, thinking skill, and information sharing skill (Agha, 2018, 21). Communication is a way to accomplish the work of the organization, and that communication must include conveying and understanding meanings and any idea whatever the skill of listening, understanding and speaking clearly so that the speaker's ideas are communicated correctly. Active communication is one of the most important soft skills of leaders, which includes active listening and feedback (Levaseur, 2013). Communication skills include oral skills, in addition 
to written skills. Cole (1999) asserts that a leader who fails to communicate with employees will reflect on their trust and loyalty, which leads to poor performance. Shahid and Asiahbinti $(2011,194)$ identify a set of skills such as speaking, writing, listening and responding as types of communication skills.

2. Time management: Time management refers to the process of utilizing the available time and personal talents of managers to achieve the important goals pursued by the organization, and to maintain a balance between requirements. Time is at the forefront of evaluation elements and indicators, and is always associated with failure and success in achieving goals within the time limit specified for that, so time management is no longer a luxury skill for the manager or worker, whether at the job level or at the organization level (Al-Tarawneh and Mubaslit, 2012, 7). Time management is a comprehensive process that is carried out through administrative functions, business and organized activities that rely in their implementation on high skills and distinguished personal talents, in order to be able to employ all possibilities to meet, rationalize and benefit from the needs of individuals and society, and to adapt to current and future circumstances (Mahdi, 2017).

3. Leadership: Balachander and Jayam (2015) refer to the soft skills of leadership as the leader's ability to develop unique and effective ways of getting work done in accordance with knowledge and people (Abdullah \& Abd al-Rahman, 2012, 408). Soft means the acquisition of non-traditional skills whose outcome is soft skills, where skills with social characteristics determine the difference that is difficult to measure (Simpson, 2013). Soft leadership capabilities are intangible personal capabilities that determine the strength and influence of individuals, and they are those skills that focus on persuading and influencing others (Rao, 2013), as well as the characteristics, characteristics, and acquisition of individuals by personal skills for leadership, which are skills that focus on empathy with a focus on the human aspects of encourage and persuade others.

4. Teamwork: The teamwork skill is one of the skills necessary to accomplish most of the work, given the need of individuals and the necessity of cooperation and teamwork tasks, for the ability to achieve and benefit from the strengths of team members to reach goals and save time and effort explained (Sairam et al., 2017). The work team consists of several individuals with multiple and different skills and integrated work dynamics to reach joint teamwork and achieve goals, and the skill of work teams is one of the leadership skills that urge the leader to exert influence on other members of the organization, and help that organization achieve goals effectively and efficiently. Teamwork involves sharing one's experiences and giving up some autonomy to work closely with team members (Heathfield, 2019).

5. Decision-making: It is a basic process and a major driver of human resources efforts, and it includes all management functions and elements, whether related to objective work goals, formulating policies, defining work systems, rules and procedures, because they are considered the backbone of management, and are directly related to achieving the required goals (Mohsin, 2019). Ziadeh (2009, 129-130) says that decision-making is a comprehensive process based on working to solve a specific problem, where many factors overlap in the organization, such as the organizational, administrative, social and psychological factors of employees, the decision maker must take these factors into account, so it has become the decision-making process is central to the managerial process, and the success of any organization depends on the ability of its management to make successful decisions. 


\section{Organizational Innovation}

The term organizational innovation refers to the application of new organizational methods such as renewal in the practical practices of the organization, the internal organization of the organization, and internal relations. The importance of organizational innovation lies in that it enables the organization to improve its performance by reducing administrative costs, improving job satisfaction, and accessing intangible assets (Ben Issa, 2016).

Organizational innovation largely means either creating or adopting a new idea or behavior for the organization (Lam, 2006, 227). By its nature transformational, innovation therefore looks at how new ideas and behaviors are portrayed in a particular organization, which work to positively influence the organization. On the other hand, it has been defined as a modern organizational method of business organization applications, which includes arranging the workplace, or external links to business organizations, the aim of which is to modernize the work of the organization by reducing management expenses, production procedures expenses, or developing the work environment, or reducing production input costs (Lousadi and Khalfawi, 2019). Abu Al-Nasr $(2009,72)$ believes that innovation requires new ways of thinking in order to reach something different and distinctive. On the other hand, there are those who believe that organizational innovation is to take advantage of distinctive and new ideas to make changes in operations, and organizational innovation plays an important role in developing the work of procedures within the organization, by updating methods related to management that allow the development of production and reduce expenses, and organizations make adjustments in organizational design, which is known as process re-engineering, which leads to shortening the arrangements of multiple functions, changing positions and duties, and removing unimportant activities, and this enhances the ease of distribution and transfer of information, and reduces time, which is reflected in reducing expenses. The organization's adoption of leadership and administrative methods that believe in equality and justice contribute to increasing the capacity of employees and their sense of a high relationship with the organization, which enhances their dedication and drives them towards innovation, which leads to the development of product quality, raising production, and ensuring a rapid response to the organization's work requirements (Bashir, 2017, 58).

1. Introducing new product: Today's environment is very competitive, and the organization cannot live in the environment in which it operates and continue to succeed by providing one product, and the reason for this is due to the short life cycle of the product, so organizations must work to confront this situation by reducing the time period for product design and delivery, the organization's ability to compete by possessing flexibility is the ability to respond to changes in the market and the actual needs expected by customers (Aquilano et al., 1995, 274). Means the introduction of a product (a new good or service), or the development and radical change of the product through the techniques used and methods of production to include the characteristics and uses of the product, and this is represented by a change. Technical specifications of the product its constituent materials, and the functions performed by that product (Tang, 2015). Heizer and Render $(1997,142)$ believe that designing a new product is key to an organization's business, and anything less than a distinct product strategy can lead the organization to completion, or that the organization has time to focus and innovate. Since all products have a finite and predictable life cycle, organizations must follow up firmly and consistently and bring the new product to market. 
2. Improving existing product: Garvin $(1984,273)$ believes that improving an existing product must depend on several methods such as performance, product characteristics, conformity to standards, reliability, ability to survive for a long time, the level of the product, whether during or after sales, and the final form that depends the marketing manager tries to break the deadlock reached by the product's image in the eyes of consumers (as evidenced by the stability of its sales at a certain limit, with a tendency to decline) by making changes in the characteristics of the product to attract new consumers, or to increase consumption rates, or usage among existing buyers, and this may lead the product to start a new life cycle if the new modification is distinctive. In general, the product can be modified in many ways, including: reducing the price to attract new customers, or withdrawing customers from competitors, changing temptations and advertising messages, conducting sales contests, distributing gifts and free samples, resorting to new, large-scale and sophisticated distribution outlets, in addition to offering the best product quality and warranty (Baalawi, 2009, 157).

3. Inventing new process: Processes are defined as a series of tasks or activities performed by an integrated group of people, equipment and tools, i.e. working to transform from inputs to outputs through a series of actions and activities that are implemented in the organization, so that these activities generate value for the customer, where process innovation begins with a good awareness of who the customers of the process are and what they expect from them, and process innovations are in the design of a new production process (lyad \& Hassan, 2010). This type of innovation is represented by changes related to the development or application of a new method of production and marketing, the goal is to increase quality, reduce production costs to satisfy customers, it means a set of procedures, processes and behaviors that improve the overall organizational climate, motivate workers to solve problems, and make decisions in a new way that was not known before (Tang, 2015). From the point of view of Kusiak (2017), process innovation is a procedural action that aims to raise quality, produce a modern product, develop it in a clear way, or a modern delivery method, or develop it in a clear way, or raise quality and reduce production expenses.

4. Improving existing process: Harem $(2004,261)$ believes that most areas covered by organizational innovation include changes in organizational structure, business design, organizational processes, new policies and strategies, and new control systems. On the other hand, Imam (2020) believes that innovation greatly improves performance in jobs and products, for example, marketing email, which helps improve performance in customer relationship management, building customer databases, to provide them with the best service, and also contributed to achieving interaction in time actual with customers to respond quickly to their needs and in a better way.

\section{Literature Review}

Otaiba study (2021) aimed to identify the challenges facing Arab higher education, reveal the reasons for the poor alignment between higher education outputs and labor market requirements, verify the nature of soft skills, and their relationship to achieving alignment with the requirements of the labor market, presenting some of the leading experiences of developed countries, and upgrading it has soft skills as one of the mechanisms to bridge the gap between the outputs and the changing needs of the labor market. The study concluded that one of the strongest reasons for the poor alignment of outputs with the requirements of the labor market is the nature of the labor market, which is directly affected by technological and production developments, and therefore it develops more quickly than the environment of organizations, in addition to globalization that has led to changing the requirements of the 
labor market, where there is a difference between the levels of education and training, and the requirements of the labor market, and the student today needs a set of skills, which guarantee him ample chances of obtaining a job and achieving a successful career path. The renewable labor market, including: communication, organization and planning, team work, adaptation and flexibility, critical thinking, crisis management, professionalism, and negotiation. As for the study of Banat and Omari (2020) it attempted to measure the effect of power and influence tactics in leadership on soft skills. The results of the study indicated that there was a statistically significant effect of strength and influence tactics on soft skills (communication and communication, teamwork, working under pressure, change management, and decision-making). In another study conducted by Hilal and Arbab (2020), which focused on clarifying the role of organizational innovation as an effective mechanism for finding solutions and alternatives to deal with crises facing the company, and knowing the organization's capabilities in finding atypical solutions that contribute to reducing the effects of crises facing the company in the presence of an environmentally friendly environment unstable. The results of the study showed that there is a direct relationship between organizational innovation and the increase in the effectiveness of the organization in the face of crises, including personal, and organizational reasons that the organization cannot control, which makes it difficult to reach a solution to them due to the overlapping of their causes and the need for a variety of methods to solve them.

On the other hand, El-Araby and others (2019) identified the level of presence of specific knowledge management processes, and the extent of their contribution to creating organizational innovations in light of unstable environmental changes. The study concluded that there is an impact relationship between the specific processes of knowledge management and the organizations' efforts to adapt to organizational changes in the environment, and the results of the study indicated that there is no relationship between adaptation and organizational change. The study aimed at Lok et al (2021) to verify the impact of training in soft skills and their development on human resources results and company performance. The study found that soft skills with their dimensions (communication, critical thinking, creative thinking, problem solving, teamwork, leadership, decision-making, and emotional intelligence) contributed significantly to human resources, but did not directly affect the performance of the company, and that there is a significant practical impact. To practice soft skills, the most important of which is the emergence of a high demand for soft skills in the current era, and that these skills are important for the success and competitiveness of companies.

As for the study of Thani et al (2021) focused on the study aimed at explaining the impact of self-development in the trend towards organizational innovation with the mediating role of human resource agility. The study concluded that there is a positive effect of selfdevelopment in the agility of human resources, and the presence of an effect of agility of human resources in the trend towards organizational innovation in its dimensions (product innovation, process innovation, and managerial innovation), and that human resource agility mediates the effect of self-development in organizational innovation, while it was not Selfdevelopment has no direct impact on the trend towards organizational innovation. Wisshak and Hochholdinger (2020) study aimed to investigate whether soft-skilled and hard-skilled trainers have different views regarding the required educational knowledge and skills. The study found that there are differences in the evaluations of managing interactions and educational activities between soft skills and hard skills trainers. There is an impact of the 
different perspectives of trainers with soft and practical skills on different educational backgrounds.

As for the study of Reichert et al (2020) it aimed to determine the values if companies with activities related to the process of strategic intelligence differ in terms of their level of innovation ability, and to verify the differences when comparing reactive and proactive groups. The results of the study indicated that development, operations and management capabilities are higher in companies where there are strategic intelligence practices, and that strategic intelligence is a way to direct business towards the future, and when it is linked to innovation, it enhances ways of understanding the new requirements of organizations. In another study conducted by Hendarman and Cantner (2020), which focused on measuring the impact of hard skills and soft skills for employees on employees' ability to innovate, and the effect of organizational learning mediation on the relationship between hard skills and soft skills and employee innovation. The study found that soft and hard skills have a positive and significant impact on employees' ability to innovate, either directly or indirectly through the mediating effect of organizational learning, and that skills, whether hard or soft, can improve company performance significantly, and that organizational learning can be a catalyst for employee knowledge creation, and company management needs to expand my business.

\section{Relationship between Soft Skills and Organizational Innovation}

The skill of foresight and problem solving as one of the dimensions of strategic intelligence has a great impact on managers who have positive competence in organizational development (Analouei et al., 2010), so managers must be characterized by high strategic intelligence to determine and choose the strategic path of their organizations (Zehir et al., 2011). Strategically intelligent managers greatly influence organizational growth and development through planning and strategic decision-making (Esmaeili, 2014).

Soft skills are essential for innovation and the economic performance of companies, where employees are considered as human capital and important actors in innovation, so companies invest in developing the skills of their employees through training, because soft skills contribute positively to the performance of the company by linking higher levels of employee skills to a higher level. of labor productivity. With regard to innovation, whether it is product innovation or process innovation, it is the special skills of employees that make companies more productive, as the relationship extends from employee skills through innovation to the productivity of the company, and training plays an important role in the relationship between soft skills and innovation, where training and management determines Innovative performance of the firm. Firms tend to innovate when their employees spend more time training to learn certain skills (Mohnen \& Hall, 2013.

The ability of employees to innovate is the engine that works on business sustainability, and performance depends on the culture of knowledge in the organization, which consists of tacit knowledge and hard skills. There are those who believe that the ability of employees to innovate is affected by the leadership style (Villaluz \& Hechanova, 2019). Company innovation is sustainable if it is based on a culture of learning that adds value. This learning culture makes all employees interact with each other so that their existing knowledge and new acquired knowledge can be effectively transferred, exchanged and integrated into the company's intelligence and knowledge (Lin \& Lee, 2017).

The organizational environment is an important factor in the ability of employees to innovate, so company management needs to build maximum participation of all employees 
to constantly improve hard skills and soft skills, and the collective learning behavior adopted in the company environment is a driving force for employee innovation (Widmann \& Mulder, 2018). The process of improving skills to improve the ability of employees to innovate should not be limited to the internal operations of the company, rather the management of the company needs to expand the process of developing innovation through efforts to assimilate, clarify, use and manage the knowledge obtained from the evil partners.

\section{Hypothesis}

Ho1 There is an impact of soft skills on organizational innovation in Lavant Food Products Company (Al Durra).

\section{Methodology \\ Sample}

The study population consists of all 140 employees in Levant Food Industry Company (AlDurra). The researchers used the comprehensive survey method in collecting data, where an electronic questionnaire was distributed to all employees and (106) questionnaires were retrieved, which were subjected to statistical analysis.

\section{Instrument}

The study tool was represented by the questionnaire that was developed by researchers after references to many previous studies and in accordance with the nature of the study and its variables. The questionnaire included the following parts:

- The first part: includes items that measure soft skills, which includes the following dimensions: communication, time management, leadership, teamwork and decision-making. Several previous studies were used to develop the items of this variable, including: (Abdullah, 2013; Al-Jarida \& Al-Alawi, 2018; Wisshak \& Hochholdinger, 2020; Aldulaimi, 2018).

- The second part: includes items that measure organizational innovation, which includes the following dimensions: innovation new product, improve existing product, innovating new process, improve existing process. Several previous studies were used to develop the paragraphs of this variable, including: (Thani et al., 2021; Jabbar \& Muhammad, 2021; Akili \& Jabbari, 2019).

A five-point scale was used to answer the study items, ranging from strongly agree with a weight of (5) to strongly disagree with a weight of (1).

\section{Results}

Table 1 presents the results of the study dimensions' reliability test using Cronbach's alpha reliability coefficient. It was found that all alpha values were greater than 0.70 , which is the minimum acceptable percentage for stability, which allows to continue with the statistical analysis of the data, as the lowest value was 0.75 for Improving existing product items.

With regard to the descriptive analysis of the study data, it was found that all the mean values for study dimensions variables were high, as for the soft skills dimensions, the lowest value for leadership was with an average of 3.79 and the highest value for communication with an average of 4.11. With regard to the dimensions of organizational innovation, the lowest value for innovating new process was reached with an average of 4.02 and the highest value for introducing new product with an average of 4.19 . 
Table 1 results of descriptive analysis

\begin{tabular}{|c|c|c|c|c|c|c|c|c|c|c|c|c|c|c|}
\hline \# & Variable & $\begin{array}{l}\text { Ite } \\
\text { ms }\end{array}$ & $\begin{array}{l}\text { Alp } \\
\text { ha }\end{array}$ & $\begin{array}{l}\text { Me } \\
\text { an }\end{array}$ & Std & 1 & 2 & 3 & 4 & 5 & 6 & 7 & 8 & 9 \\
\hline 1 & $\begin{array}{l}\text { Communicati } \\
\text { on }\end{array}$ & 5 & 0.79 & $\begin{array}{l}4.1 \\
1\end{array}$ & $\begin{array}{l}0.6 \\
0\end{array}$ & & & & & & & & & \\
\hline 2 & $\begin{array}{l}\text { Time } \\
\text { management }\end{array}$ & 5 & 0.85 & $\begin{array}{l}3.9 \\
9\end{array}$ & $\begin{array}{l}0.6 \\
5 \\
\end{array}$ & $\begin{array}{l}0.4 \\
7\end{array}$ & & & & & & & & \\
\hline 3 & Leadership & 5 & 0.79 & $\begin{array}{l}3.7 \\
9\end{array}$ & $\begin{array}{l}0.7 \\
3\end{array}$ & $\begin{array}{l}0.0 \\
1\end{array}$ & $\begin{array}{l}0.3 \\
2 \\
\end{array}$ & & & & & & & \\
\hline 4 & Teamwork & 5 & 0.85 & $\begin{array}{l}4.0 \\
9\end{array}$ & $\begin{array}{l}0.6 \\
3\end{array}$ & $\begin{array}{l}0.4 \\
0\end{array}$ & $\begin{array}{l}0.5 \\
6\end{array}$ & $\begin{array}{l}0.3 \\
7\end{array}$ & & & & & & \\
\hline 5 & $\begin{array}{l}\text { Decision } \\
\text { making }\end{array}$ & 5 & 0.83 & $\begin{array}{l}3.8 \\
4\end{array}$ & $\begin{array}{l}0.6 \\
4\end{array}$ & $\begin{array}{l}0.0 \\
1\end{array}$ & $\begin{array}{l}0.4 \\
2\end{array}$ & $\begin{array}{l}0.4 \\
9\end{array}$ & $\begin{array}{l}0.4 \\
0\end{array}$ & & & & & \\
\hline 6 & $\begin{array}{l}\text { Introduction } \\
\text { new product }\end{array}$ & 5 & 0.80 & $\begin{array}{l}4.1 \\
9\end{array}$ & $\begin{array}{l}0.5 \\
1\end{array}$ & $\begin{array}{l}0.1 \\
3\end{array}$ & $\begin{array}{l}0.2 \\
3\end{array}$ & $\begin{array}{l}0.2 \\
8\end{array}$ & $\begin{array}{l}0.3 \\
4\end{array}$ & $\begin{array}{l}0.2 \\
9\end{array}$ & & & & \\
\hline 7 & $\begin{array}{l}\text { Improve } \\
\text { existing } \\
\text { product }\end{array}$ & 5 & 0.75 & $\begin{array}{l}4.1 \\
2\end{array}$ & $\begin{array}{l}0.4 \\
7\end{array}$ & $\begin{array}{l}0.0 \\
3\end{array}$ & $\begin{array}{l}0.2 \\
2\end{array}$ & $\begin{array}{l}0.4 \\
2\end{array}$ & $\begin{array}{l}0.2 \\
5\end{array}$ & $\begin{array}{l}0.3 \\
6\end{array}$ & $\begin{array}{l}0.6 \\
9\end{array}$ & & & \\
\hline 8 & $\begin{array}{l}\text { Innovating } \\
\text { new process }\end{array}$ & 5 & 0.81 & $\begin{array}{l}4.0 \\
2\end{array}$ & $\begin{array}{l}0.5 \\
3\end{array}$ & $\begin{array}{l}0.0 \\
2\end{array}$ & $\begin{array}{l}0.2 \\
2\end{array}$ & $\begin{array}{l}0.4 \\
6\end{array}$ & $\begin{array}{l}0.3 \\
9\end{array}$ & $\begin{array}{l}0.4 \\
9\end{array}$ & $\begin{array}{l}0.6 \\
5\end{array}$ & $\begin{array}{l}0.6 \\
6\end{array}$ & & \\
\hline 9 & $\begin{array}{l}\text { Improve } \\
\text { existing } \\
\text { process }\end{array}$ & 5 & 0.86 & $\begin{array}{l}4.0 \\
7\end{array}$ & $\begin{array}{l}0.5 \\
9\end{array}$ & $\begin{array}{l}0.1 \\
1\end{array}$ & $\begin{array}{l}0.3 \\
1\end{array}$ & $\begin{array}{l}0.5 \\
0\end{array}$ & $\begin{array}{l}0.3 \\
4\end{array}$ & $\begin{array}{l}0.4 \\
1\end{array}$ & $\begin{array}{l}0.5 \\
4\end{array}$ & $\begin{array}{l}0.6 \\
6\end{array}$ & $\begin{array}{l}0.7 \\
1\end{array}$ & \\
\hline
\end{tabular}

Table 2 indicates the results of the linear regression analysis of the impact of soft skills on organizational innovation. The results showed that there is a significant impact of soft skills on organizational innovation, where the value of $(R 2=32)$ this means that soft skills explain $32 \%$ of the variance in innovation. The value of $(F=9.37)$ and a significant level of $(0.00)$ and $T$ values had a significant impact on two dimensions of soft skills: leadership and decisionmaking on organizational innovation.

Table 2 impact of soft skills on organizational innovation

\begin{tabular}{|l|r|r|r|}
\hline Variable & $\mathrm{B}$ & $\mathrm{T}$ & Sig. \\
\hline Communication & 0.01 & 0.11 & 0.91 \\
\hline Time management & 0.01 & 0.13 & 0.90 \\
\hline Leadership & 0.19 & 3.15 & 0.00 \\
\hline Teamwork & 0.13 & 1.74 & 0.09 \\
\hline Decision making & 0.16 & 2.15 & 0.03 \\
\hline \multicolumn{2}{|c|}{$\mathrm{R}^{2}=0.319$} & $\mathrm{~F}=9.37$ & Sig. $=0.00$ \\
\hline
\end{tabular}

Table 3 presents the results of the stepwise regression analysis of the impact of the dimensions of soft skills on organizational innovation, where the results in the first model showed that the most influential dimensions of soft skills in organizational innovation are leadership, leadership explains $24 \%$ of the variance in organizational innovation, but in the second model and after added decision-making, the interpretation of the two dimensions of the variance in organizational innovation increased and became $29 \%$. As for the third model, in which the teamwork was added to leadership and decision-making, the interpretation of 
the variance increased to $32 \%$. As for the two dimensions communication and time management, their impact was not significant.

Table 3 stepwise impact of soft skills on organizational innovation

\begin{tabular}{|c|c|c|c|c|c|c|c|}
\hline Model & Variable & B & $\mathrm{T}$ & Sig. & $\mathrm{R}^{2}$ & $\mathrm{~F}$ & Sig. \\
\hline 1 & Leadership & 0.30 & 5.65 & 0.00 & 0.24 & 31.95 & 0.00 \\
\hline \multirow[t]{2}{*}{2} & \multirow{2}{*}{$\begin{array}{l}\text { Leadership } \\
\text { Decision-Making }\end{array}$} & 0.22 & 3.68 & 0.00 & \multirow[t]{2}{*}{0.29} & \multirow[t]{2}{*}{21.13} & \multirow[t]{2}{*}{0.00} \\
\hline & & 0.19 & 2.85 & 0.01 & & & \\
\hline \multirow[t]{3}{*}{3} & \multirow{3}{*}{$\begin{array}{l}\text { Leadership } \\
\text { Decision-Making } \\
\text { Teamwork }\end{array}$} & 0.19 & 3.19 & 0.00 & \multirow[t]{3}{*}{0.32} & \multirow[t]{3}{*}{15.91} & \multirow[t]{3}{*}{0.00} \\
\hline & & 0.16 & 2.25 & 0.03 & & & \\
\hline & & 0.13 & 2.05 & 0.04 & & & \\
\hline
\end{tabular}

\section{Discussion}

The study aimed to verify the impact of soft skills on organizational innovation in Lavant Food Products Company (AIDurra). The researchers collected the necessary data for this study and used many statistical transactions. The study found that there are high levels of soft skills dimensions in the company, especially with regard to including the communication between employees, which is interspersed with discussion and dialogue to find solutions to the problems they face, and this is achieved due to the tendency of the company's management to complete its work using teamwork, but it is noted that the leadership style used by the company's management is somewhat inconsistent with the way the work is done through teamwork, which produced ample space for communication between employees.

The study results indicated that there are high levels of organizational innovation dimensions, whether related to product innovation or process innovation. The company pays great attention to introducing new products, as well as to improving existing products, and so on with regard to operations, and what supports this orientation is the use of the teamwork method and communication capacity granted by management to employees.

The results showed that there is a clear impact of soft skills on organizational innovation, especially with regard to leadership skills, decision-making and teamwork. The existence of a motivating leadership for employees and capable of creating an appropriate work climate that motivates employees, and pays attention to individual differences between them, and to benefit from all employees' ideas by motivating them intellectually, in addition to the management's participation of employees in the decision-making process and reliance on collective decisions, which clearly contributed to the employees' interest in innovation, in addition to the adoption of teamwork that help employees diversify their skills and complete the image of projects that need to be transferred to the reality of application.

\section{Recommendations}

1. Increasing the company's interest in applying modern leadership methods that depend on the intellectual stimulation of employees, achieving cooperation between them, hearing their ideas and adopting teamwork to implement these ideas.

2. Increasing the company's interest in the method of decision-making and giving the most attention to the human side which depends on the collective decision, in order to exploit all the capabilities of the employees.

3. Enhancing the capabilities of employees in proposing innovative operations to implement business as an alternative to the existing operations, which depend on the use of technology that ensures that these operations are carried out faster and more accurately. 


\section{References}

Abdullah, K. (2013). The soft skills they are looking for. Vision Foundation for Press and Publishing.

Abu Al-Nasr, M. M. (2009). Innovative and creative thinking is a way to excellence and success. The Arab Group for Training and Publishing.

Agha, M. (2018). Soft skills and their relationship to job performance among workers in banks in the governorates of Palestine, an applied study on workers in banks in the southern governorates of Palestine. Master's thesis, Al-Azhar University - Gaza.

Akili, O. M., \& Jabbari, H. Y. (2019). The application of (RFID) technology in the transformation towards growth and intelligence in business enterprises in the Jazan region: the Saudi Electricity Company as a model. Tenth International Scientific Conference. http://proceedings.sriweb.org

Aldulaimi, S. H. (2018). Leadership soft skills in higher education institutions. Social Science Learning Education Journal, 3(7), 01-08.

Al-Jaraydah, M. S., \& Al-Alawi, S. H. (2018). The degree of school principals practicing soft skills in the Wilayat of Sur in the Sultanate of Oman. Arab research in the fields of specific education. Arabic Research in Specific Education Journals, (12), 255-278.

Al-Tarawneh, M., \& Hussein, M. (2012). Time management: The skills of managers and employees to use time to effectively improve their performance. Dar Safaa for Publishing and Distribution.

Analoui, F., Ahmed, A. A., \& Kakabadse, N. (2010), Parameters of managerial effectiveness: The case of senior managers in the Muscat Municipality, Oman. Journal of Management Development, 29(1), 56-78.

Aquilano, N. J., Chase, R. B., \& Daves Mark M., (1995). Fundamentals of operations (2 ${ }^{\text {nd }}$ Ed.), Irwin.

Asbari, M., Nurhayati, W., \& Purwanto, A. (2019). Pengaruh parenting style dan personality genetic terhadap pengembangan karakter anak di paud islamic company. Jurnal Ilmiah Kajian IImu Anak dan Media Informasi, 4(2), 148-163.

Doi:http://dx.doi.org/10.33061/jai.v4i2.3344.

Ba'Alawi, A. A. (2009). Principles of marketing. Dar Al Fikr Library.

Balachander, S., \& Jayam, R. (2015), A study on the "soft skill requirements" and suggested training for student community at colleges in today's context. International, journal of management and Social Science Research Review, 1(10), 93-111.

Banat, A. M., \& Al-Omari, G. I. (2021). Power and influence tactics in leadership and their impact on soft skills in IT companies in Jordan. Amman Arab University Journal of Research, 6(1), 67-83.

Bashir, N. (2017). Organizational effectiveness between theory and practice (6 $6^{\text {th }}$ ed.). The Modern World of Books.

Benissa, L. (2016). The role of innovation in improving the performance of the institution from the perspective of the balanced scorecard. Journal of Human Sciences, (29), 44-148.

Cole, M. A. (1999). Become the leader followers want to follow. Journal of Supervision, 60(12), $182-198$.

Esmaeili, M. R. (2014). A study on the effect of the strategic intelligence on decision making and strategic planning. International Journal of Asian Social Science, 4(10), 1045-1061.

Eyad, M. A., \& Hassan, D. (2010). The effect of process creativity on product design: a case study in the general company for electrical industries. The Iraqi Administrative Journal of Science, 27(7), 65-76. 
Garvin, D. (1984). Competing in the eight dimensions of quality. Harvard Business.

Gibb, S. (2014). Soft skills assessment: theory development and the research agenda. International Journal of Lifelong Education, 33(4), 455-471, doi: 10.1080/02601370.2013.867546

Gregory, H. A. (1999). Automating business process reengineering ( ${ }^{\text {rd }}$ Ed.), Prentice-Hall Publishing.

Harem, H. (2004). Organizational behavior: The behavior of individuals and groups in business organizations. Dar Al-Hamid for Publishing and Distribution.

Hazier, J., \& Render, B. (1997). Operation management ( $2^{\text {nd }}$ Ed.). J. and Render.

Heathfield, S. (2006). A definition of team and the common type.

Hendarman, A. F., \& Cantner U. (2018). Soft skills, hard skills, and individual innovativeness. Eurasian Business Review, 8(2), 139-169. DOI:10.1007/s40821-0170076-6.

He, P., Wu, T., Zhao, H., \& Yang, Y. (2019). How to motivate employees for sustained innovation behavior in job stressors? A cross-level analysis of organizational innovation climate. International Journal of Environmental Research and Public Health, 16(4608), 1-14. doi:10.3390/ijerph16234608.

Hilal, T. O. A., \& Arbab, S. A. (2020). The impact of organizational innovation in crisis management: a field study on the employees of the Sudanese Egyptian Company for Electrical Industries (Sudatraf). Journal of the Islamic University of Economic and Administrative Studies, 28(3), 158-175.

Imam, A. K. (2020). Innovative thought and its representations in interior space design. Academic Journal, (95), 195-208.

Jabbar, D. M., \& Muhammad, A. A. (2021). The effect of technical creativity on human resource prowess through career engagement. Journal of Economic and Administrative Sciences, 27(125), 265-293. http://jeasiq.uobaghdad.edu.iq

Junrat, S., Jenphop, C., Suravee, R., \& Kanokorn, S. (2014). Soft skills for university library staff in Thailand. Procedia-Social and Behavioral Sciences, 112, 1027-1032.

Kusiak, A. (2017). Innovation: The living laboratory perspective. Computer-Aided Design and Applications, 4(6), 863-876.

Lam, A. (2006). Organizational innovation, In: Fagerberg et al., The Oxford Handbook of Innovation, Oxford University Press, Oxford.

Levasseur, R. E. (2013). People skills: Developing soft skills -A change management perspective. Walden University, 43(6), 381-399.

Lin, H., \& Lee, Y. (2017). A study of the influence of organizational learning on employees' innovative behavior and work engagement by a cross-level examination. Eurasia Journal of Mathematics, Science and Technology Education, 13(7), 3463-3478. https://doi.org/10.12973/eurasia.2017.00738a

Lok, B., Cheng, M., \& Choong, Ch. (2021). The relationship between soft skills training and development, human resource outcome and firm performance. International Journal of Business and Society, 22(1), 382-402. https://doi.org/10.33736/ijbs.3184.2021.

Lusadi, F. A., \& Khalfawi, H. (2019). The impact of marketing innovation on enhancing the Algerian customer's loyalty to the brand: A case study of the LG Electronics Company. Journal of North African Economics, (20), 259-276.

Mahdi, J. (2017). Time management and work stress relationship and influence. An intentional analytical study on the heads of departments at the Technical Institute / Mohamed, M. Sh. (2019). Determining the goals of strategic intelligence to achieve the 
requirements of intellectual capital. Journal of Baghdad College of Economic Sciences, 58 (6), 123-141.

Marengo, A., \& Pagano, A. (2020). Innovative ways to assess soft-skills: The in-basket game online experience. Proceedings of the European Conference on e-Learning. 2020, 325334. DOI:10.34190/EEL.20.037.

Mohsen, M. (2019). Crisis management for the deans of faculties at Al-Mustansiriya University and its relationship to effective decision-making from the point of view of the teachers. Journal of Educational College, (34), 548-515.

Moss, P., \& Tilly, C. (1996). "Soft" skills and race: An investigation of black men's employment problems. Work and Occupations, 23(3), 252-276.

Otaiba, A. M. H. (2021). Soft skills: An introduction to the harmonization of university outputs with the requirements of the labor market. Journal of Educational and Quality Research, 5(5), 67-86.

Ramesh, G., \& Ramesh, M. (2020). Soft skills attitude, communication and etiquette for success. Dorling Kindersley(INDIA) Pvt. Ltd.

Rao, M. S. (2013). Soft leadership: A new direction to leadership. Journal of Industrial and Commercial Training, 45(3), 38-49.

Reddy, G. (2013). Soft skills for mangers. Carolinian publishing.

Reichert, F. M., Janissek-Muniz, R., Heinze, M., de Souza Cainelli, A., \& Zawislak, P. A. (2020). Innovation capabilities and the role of strategic Intelligence. https://www.msn.com/enus/feed

Robels, M. M. (2012). Executive perceptions of the top 10 soft skills needed in today's workplace. Business Communication Quarterly, 75(4), 453-465.

Sairam, S., Wisetrinthong, B., Chaiyuth, K. (2017). Development of program to enhance team building leadership skills of primary school administrator. International Education Studies, 10(7), 143-154.

Shahid, S., Asiahbinti, M. (2011). A Study on perceived leadership soft skills, trustworthiness and structure empowerment of deans in the three Malaysian public universities, PhD Thesis, University Saints Malaysia.

Simpson, H. A. (2013). Public administration in today's world organization and markets. Journal of Political Science Politics, 33(4), 271-287.

Tang, Y. (2015). The impact of organizational culture, leadership style, and organizational learning on organizational innovation in the public sector. Journal of Quality, (22), 461481.

Thani, N. F., Mazari, E., Asadi, S., \& Mashayekhikhi, M. (2021). The impact of selfdevelopment on the tendency toward organizational innovation in higher education institutions with the mediating role of human resource agility. Journal of Applied Research in Higher Education, doi:10.1108/JARHE-05-2020-0151

Vijayalalshmi, V. (2016). Soft skills-the need of the hour for professional competence: A review on interpersonal skills and skills theory. International Journal of Applied Engineering Research, 11(4), 2859-2864.

Villaluz, V., \& Hechanova, M. (2019), Ownership and leadership in building an innovation culture. Leadership\& Organization Development Journal, 40(2), 138-150. https://doi.org/10.1108/LODJ-05-2018-0184

Widmann, A., \& Mulder, R. (2018). Team learning behaviours and innovative work behaviour in work teams. European Journal of InnovationManagement, 21(3), 501-520. https://doi.org/10.1108/EJIM-12-2017-0194 
Wisshak, S., \& Hochholdinger, S. (2020). Percieved instructional requirements of soft-skills trainers and hard-skills trainers. Journal of Workplace Learning, 32(6), 405-41 DOI.10.1108/JWL-02-2020-0029.

Ziadeh, F. (2009). Management jobs. Dar Al Yazouri Scientific for Publishing and Distribution. Zehir, C., Ertosun, O. G., Zehir, S., \& Muceldili, B. (2011). The effects of leadership styles and organizational culture over firm performance: Multi-national companies in istanbul. ProcediaSocial and Behavioral Sciences, (24), 294-304. 